\title{
Franciszek Skoryna i inni drukarze z Wielkiego Księstwa Litewskiego i Korony Polskiej na łamach wileńskiej prasy białoruskojęzycznej w latach 1909-1918
}

\section{Przyczynek do dziejów kształtowania białoruskich stereotypów narodowych}

Na początku XX wieku w Wilnie w prasie białoruskojęzycznej zaczęły się pojawiać publikacje poświęcone wydawnictwom pierwszych książek w języku cerkiewnosłowiańskim i ruskim w Wielkim Księstwie Litewskim i Królestwie Polskim. W artykułach autorstwa znanego publicysty Wacława Łastowskiego początkowo twierdzono, że założycielem białoruskiego druku był drukarz krakowski Szwajpolt Fiol. Następnie za pierwszego wydawcę książek białoruskich uznano Franciszka Skorynę z Połocka. Od tamtego czasu Skoryna w umysłach Białorusinów był białoruskim drukarzem, chociaż w jego epoce (XVI wiek) naród białoruski jeszcze nie istniał, a Skoryna uważał się za Rusina, czyli przedstawiciela społeczności, która obejmowała przodków Białorusinów i Ukraińców, a także mieszkańców Wielkiego Księstwa Moskiewskiego. Białoruscy publicyści z powodzeniem wykorzystali osobowość Skoryny do stworzenia idei istnienia białoruskiej kultury i języka w XVI wieku oraz ich wysokiego poziomu rozwoju. Był to ważny etap w procesie kształtowania białoruskiej idei narodowej na początku XX wieku.

Słowa kluczowe: Szwajpolt Fiol, Franciszek Skoryna, Wacław Łastowski, Wilno, Białoruś 
Białoruska idea narodowa to system wartości, który zawiera pewne stereotypy o przeszłości wyobrażanego lub rzeczywistego narodu białoruskiego. W systemie tym obecne są też w określony sposób zinterpretowane fakty historyczne i mity o narodzie powstałe w trakcie kreowania owej idei. W szczegółach białoruska idea narodowa może pokrywać się z polską, litewską, ukraińską, rosyjską wizją przeszłości, teraźniejszości oraz przyszłości na skutek zbiegu historycznych okoliczności, które miały lub mają wpływ zarówno na losy przodków, jak i na dzisiejszych obywateli Białorusi, Litwy, Polski, Ukrainy, Rosji.

Analiza procesu kreowania białoruskiej idei narodowej domaga się sporządzenia tabeli danych, która ilustrowałaby działalność białoruskich aktywistów narodowych dotyczącą zarówno odrębności Białorusinów od wszystkich sąsiadów, jak i odrębności Białorusinów od niektórych sąsiadów oraz wspólnych cech (dróg historycznych) z (niektórymi) sąsiadami, co jest niezwykle trudnym zadaniem dla jednego badacza. Udział w podobnym przedsięwzięciu musiałoby wziąć grono naukowców z różnych dziedzin: historii, językoznawstwa, etnologii itd. Jednak, jak wydaje się autorowi, potrafi on zestawić podstawowe stereotypy, które pozwoliłyby sformułować podstawy białoruskiej idei narodowej w jej wersji z lat 1906-1918.

W niniejszym artykule podjęto próbę uściślenia sposobu, w jaki postacie Franciszka Skoryny oraz innych drukarzy z Wielkiego Księstwa Litewskiego i Korony Polskiej końca XV-XVI wieku zostały częścią białoruskich stereotypów narodowych, a stało się to nieprzypadkowo. Badacz problematyki świadomości narodowej Roman Szul słusznie bowiem zauważył, że „Mity i wymyślone obyczaje, żeby znaleźć się w pamięci zbiorowej, muszą spotkać się z popytem"1.

Od roku 1906 wraz z pojawieniem się na rynku wydawniczym pierwszych czasopism w języku białoruskim „Nasza Dola” i „Nasza Niwa” zaczęła się aktywna legalna działalność oświatowa prowadzona przez inteligencję białoruską, która dążyła do uświadomienia narodowego Biało-

${ }^{1}$ R. Szul, Język. Naród. Państwo. Język jako zjawisko polityczne, Warszawa 2009, s. 33. 
rusinów. Działania te wiązały się z poznawaniem dziejów ojczyzny, a jednocześnie odbywało się konstruowanie wizji przeszłości białoruskiej.

Znaczenie historii kraju dla kształtowania białoruskiej idei narodowej stało się niezwykle ważne. Stworzenie narodowej wizji przeszłości od końca XVIII wieku było koniecznością dla każdego nowo powstającego lub odradzającego się narodu Europy. Jak trafnie zaznaczył Miroslav Hroch:

obraz nowoczesnego narodu byl skierowany ku przyszłości, ale miat zawsze także swój historyczny aspekt. Wspomnienie o tym, „czym byliśmy”, ,jak cierpieliśmy”, „,czego dokonaliśmy” itd. było zawsze składnikiem narodowej agitacji i znalazło się bardzo szybko wśród stereotypów narodowych ${ }^{2}$.

Jedną z cech konstruowania białoruskiej wizji przeszłości narodowej było zawłaszczenie przez Białorusinów dziedzictwa Wielkiego Księstwa Litewskiego, Rzeczypospolitej oraz Rusi Kijowskiej. Problem jednak polegał na tym, że w wymienionych państwach przodkowie Białorusinów nie byli znani pod tym etnonimem (mogli występować jako „Biali Rusini” dopiero od końca XVI w.); nazywano ich „Rusinami”, „Litwinami” bądź „Polakami”. W związku z powyższym działacze ruchu białoruskiego mieli poważny kłopot z wyodrębnieniem ,białoruskiej” przeszłości ze wspólnej historii, którą Białorusini dzielili z Litwinami, Polakami i Ukraińcami.

Dopiero w 1909 roku na łamach „Naszej Niwy” zrodziła się idea tożsamości dawnej zachodniej Rusi a późniejszej Białej Rusi, chociaż do końca tych terminów nie utożsamiano.

U zachodnaj (biełaj) Rusi aświeta, jak na tyje časy, stajała wielmi wysoka; patreba drukawanaho słowa była tak wialikaj, što Zachodnia-Ruskije lepšyje ludzi, kab zdawolić duchowyje patreby swajho kraju załažyli drukarniủ ${ }^{3}$.

${ }^{2}$ M. Hroch, Małe narody Europy. Perspektywa historyczna, Wrocław-WarszawaKraków 2003, s. 127.

${ }^{3}$ Kali drukawałasia pieršaja biełaruskaja Biblija?, „Nasza Niwa” 1909, nr 39, s. 562. 
Chodzi tu o drukarnię Szwajpolta Fiola w Krakowie. Warto wspomnieć, że termin ,zachodnioruski” był wówczas używany przez historiografię rosyjską w odniesieniu do kultury ruskiej Wielkiego Księstwa Litewskiego, zwanego „Państwem Litewsko-Ruskim” (ros. Литовско-Pусское государство). Termin ten przedostał się do literatury białoruskiej, lecz został zamieniony na „Państwo Białorusko-Litewskie” (biał. Беларуска-Літоўская дзяржава). Owo państwo zaczęto nawet traktować jako całkowicie białoruskie, ale tendencja ta zarysowała się dopiero w latach dwudziestych XX wieku i później.

Publicyści białoruscy na początku $\mathrm{XX}$ wieku mieli świadomość istnienia przynajmniej do końca XVIII wieku wspólnego dla przodków zarówno Białorusinów, jak i Ukraińców języka literackiego. Oto co na ten temat pisał jeden z najaktywniejszych autorów gazety „Nasza Niwa” Romuald Ziemkiewicz w 1911 roku:

Knižki, drukawanyje biełarusami i ukraincami, razychodzilisia tysiačami i na Biełarusi i na Ukrainie. Možna skazać, što nie było takoj biblioteki ŭ abodwych narodoŭ, dzie nie było by knižek, drukawanych ci $\breve{u}$ Wilni, ci u Kijewi, ci u Lwowi. Hetaki wialiki abmien knižkami rabiǔsia zatym, što napisany jany byli $\breve{u}$ adnej supolnaj mowie, lohka zrazumiełaj i dla biełarusoŭ i dla ukraincoŭ.

Dziakujučy supolnaści knižnaj mowy, biełarusy i ukraincy karystali, značyć $i$ z adnej supolnaj literatury. Hetak byto i ŭ časi nacionalnaho upadku abodwych narodoŭ - da kanca XVIII stalećcia, pakul narodnyje mowy - biełaruskaja i ukrainskaja - nie zrabilisia mowami literaturnymi. Tady tolki nastupiǔ razdziet $i$ u literatury, $i$ kožny z hetych dwuch bratnich narodoŭ pajšoŭ u žyćcio swaim ŭłasnym šlacham ${ }^{4}$.

Wśród działaczy białoruskich w drugim dziesięcioleciu XX wieku istniała świadomość językowej i kulturalnej więzi tak z Rosjanami, jak i z Ukraińcami, a także przynależności do wspólnoty ruskiej. Na przykład pisarz Maksym Bohdanowicz (biał. Максім Богдановіч, Максім Багдановіч, Maksim Bohdanowič, Maksim Bahdanovič) w artykule

\footnotetext{
${ }^{4}$ R. Ziemkiewič, Taras Šewčenko i biełarusy, „Nasza Niwa” 1911, nr 8, s. 117.
} 
przypuszczalnie z 1915, a wydrukowanym w kwietniu 1918 roku na łamach mińskiej gazety „Вольная Беларусь”, pisał, że

рускіх народаў тры. [...] Адзін рускі народ жыве пад Масквою $і$ далі; завецияа ён велікарускім. Другі жыве пад Кіевам $і$ завециа ўкраінскім.

Mbl - трэці народ рускага кораню, завёмся беларусамі, і старонка наша завецияа Беларусь5.

Analiza wileńskiej białoruskojęzycznej prasy początku XX wieku wykazuje, iż pierwotnie za pionierów druku ,białoruskiego” działacze młodego ruchu białoruskiego uważali Szwajpolta Fiola i Franciszka Skorynę (w artykułach lat 1909-1916). Natomiast w 1917 roku Skoryna pozostał już jedynym pionierem drukarstwa białoruskiego.

Największe zasługi w popularyzacji dziedzictwa Skoryny i jego następców - drukarzy z państw Jagiellonów końca XV-XVI stulecia miał Wacław Łastowski (biał. Wacłaŭ Łastoŭski, Vacłaŭ Łastoŭski, Vaclaŭ Lastoŭski, Ваилаў Ластоўскі). Łastowski, przedstawiając swoje pierwsze wizje historii wydawnictwa białoruskiego, za pioniera druku w języku białoruskim uważał nie Skorynę, lecz Szwajpolta Fiola. Po raz pierwszy drukarnia Fiola pojawiła się na łamach prasy białoruskiej w 1909 roku w artykule anonimowego autora. Co prawda nie podano w tym tekście imienia Fiola, stwierdzono jednak, że

Zachodnia-Ruskije lepšyje ludzi, kab zdawolić duchowyje patreby swajho kraju załažyli drukarniu. Pieršaja Biełaruskaja drukarnia była załožena ŭ Krakowi. I ŭ 1483 hodu wyjšła z hetaj drukarni pieršaja bie-

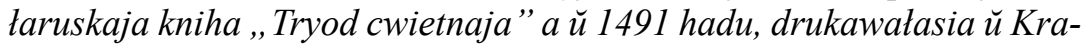
kowi užo druhaja biełaruskaja kniha ,Oktoich”.

W tym samym artykule doszło do zniekształcenia rzeczywistości: „Pieršaja Polskaja drukarnia załožena była takže u Krakowi ŭ 1505

${ }^{5}$ М. Багдановіч, Поўны збор твораў. У 3 m. Т. 3. Публіџыстыька, лісты, летапіс жыция і творчасиі, Mińsk 1995, s. 126, 310.

${ }^{6}$ Kali drukawatasia..., s. 562. 
hadu, jak bačym, praz 22 hady pośle nadrukowańnia pieršaj biełaruskaj knihi"”. Przy czym wiadomo, że początki drukarstwa w Polsce sięgają 1473 roku, a w języku polskim zaczęto drukować książki w 1513 roku .

W pierwszej syntezie dziejów Białorusi w języku białoruskim, $\mathrm{Ka}$ rotkaja historyja Biełarusi, drukowanej początkowo jako cykl artykułów w gazecie „Nasza Niwa”, a następnie wydanej w formie książkowej $(1910)^{9}$, Łastowski pisał, że:

$\breve{u}$ Krakowie raniej była atkryta biełaruskaja drukarnia, čym polskaja: U 1483 hadu nadrukowana u Krakowie pieršaja biełaruskaja kniha „, Triod Cwietnaja” a ŭ 1491 tak sama u Krakowie, Fiol rodam z Niemieččyny, drukawaŭ ǔžo druhuju knihu ,, Oktoich"”.

Z kolei w artykule z 1914 roku, poświęconym 350 rocznicy powstania drukarstwa w Moskwie, Łastowski podkreślał:

Друкарство у Беларусь зашло у канцьь XV сталецьия. Фіоль у 14911493 гаду друкаваў кнігі для Беларусі $і$ Украйны у Кракаве, а праз 23 гады полачкі жыхар Франиішак Скарына друкаваў ужо „дзеля лепшаго выразуменьня” Біблію па беларуску у Празе ${ }^{11}$.

Ważne jest tu uznanie Fiola za działacza kulturalnego nie tylko Białorusi, ale i Ukrainy.

Na łamach gazety „Homan” z 15 lutego 1916 roku ukazał się artykuł Łastowskiego 1491-1916, w którym autor po raz kolejny zaprezentował swoje wcześniejsze stanowisko:

Leta 1491 dakonczeny byli pierszyje druki biełaruskije Szwajpoltam Fiolam u mieści Krakowi.

${ }^{7}$ Ibidem.

${ }^{8}$ Z. Klemensiewicz, Historia języka polskiego. Cz. II. Doba średniopolska (od początków XVI wieku do ósmego dziesięciolecia XVIII wieku), Warszawa 1965, s. 49-50.

${ }^{9}$ Włast, Karotkaja historyja Biełarusi. Z 40 rysunkami, Wilnia 1910.

${ }^{10}$ Włast, Karotkaja historyja Biełarusi, „Nasza Niwa” 1910, nr 8, s. 126.

${ }^{11}$ Власт, 350 летняя гадаушчына друку у Маскоушчыне, „Наша Ніва” 1914, nr $11-12$, s. 1 . 
Heta byli naahut pierszyje knižki, drukawanyje u stawianskaj mowi. Drukawalisia jany z biełaruskimi asobiennaściami u mowie, - kosztam i nakładam biełaruskich panoŭ i kniažat - dla biełaruskaho narodu, i imi paczynajecca biełaruskaja drukawanaja literatura ${ }^{12}$.

Wiadomo, że Fiol był Niemcem, przybyłym do Krakowa z miasta Neustadt an der Aisch. Z zawodu hafciarz, zajmował się sporządzaniem szat kościelnych i malowaniem obrazów. Interesował się górnictwem i dzięki temu zbliżył się do rajcy krakowskiego Jana Turzona. Za jego pieniądze w 1483 roku Fiol założył w Krakowie drukarnię, w której wydawano księgi w języku cerkiewnosłowiańskim. W 1491 roku Fiola oskarżono o herezję i uwięziono, a rok później kapituła gnieźnieńska zabroniła dalszego drukowania nowych ksiąg i sprzedaży już wydanych.

Nie istnieją żadne dane o współpracy „białoruskich” panów i książąt $\mathrm{z}$ wydawnictwem Fiola, lecz Łastowski nie bez powodu uważał Fiola za pioniera druku białoruskiego. Faktycznie był on pierwszym wydawcą ksiąg dla ziem ruskich Korony Polskiej i Wielkiego Księstwa Litewskiego - terenów przyszłej Białorusi i Ukrainy.

Urodzony w końcu XV wieku w Połocku Franciszek Skoryna dobrze „nadawał się” na bohatera białoruskiej przeszłości konstruowanej przez XX-wiecznych działaczy białoruskich. Księgi Pisma Świętego, wydane po raz pierwszy w Pradze w roku 1517 i w latach kolejnych, nazywał Skoryna Biblia Ruska (rus. Бивлия Руска).

W XVI wieku język literacki, który był kontynuacją języka pisanego Rusi Kijowskiej, w Wielkim Księstwie Litewskim i Królestwie Polskim nazywano ruskim. Jego spadkobiercami są współczesne języki białoruski i ukraiński. Skoryna zaś nie określał siebie jako Białorusina czy Ukraińca. Dlaczego więc przez działaczy białoruskich uważany był za człowieka narodowości białoruskiej?

W czasach poprzedzających działalność literacką Łastowskiego spuścizna Skoryny oraz innych ówczesnych drukarzy w znacznym stopniu została zbadana przez uczonych. Pierwsze wzmianki w literaturze na-

${ }^{12}$ W. Ł., 1491-1916, „Homan” 1916, nr 1, s. 2. 
ukowej o Skorynie i jego dziełach datowane są na połowę XVIII wieku. Wśród autorów poruszających ten temat byli Niemcy (od 1740), Rosjanie (1777, 1783), Austriacy (1795), Anglicy (1813), Czesi (1814), Polacy (1815), Ukraińcy (1865) oraz polsko- i rosyjskojęzyczni badacze przełomu XIX i XX wieku z Białorusi (Adam Honory Kirkor, Mitrofan Downar-Zapolski, Jewfimij Karski). Wraz ze spuścizną Skoryny badana była działalność Szwajpolta Fiola i Wasyla Ciapińskiego. Skoryna przez uczonych spoza Białorusi uważany był za drukarza ruskiego, rosyjskiego, chociaż wspominano o jego pochodzeniu z Połocka, z ziem białoruskich ${ }^{13}$.

Po raz pierwszy imię Skoryny pojawiło się na łamach prasy białoruskojęzycznej w 1909 roku w anonimowym artykule Kali drukawatasia pieršaja biełaruskaja Biblija?:

Pieršaja Biełaruskaja Biblija pierettumačena była z tacinskaj mowy na Biełaruskuju Franciškam Skarynaj z Połocka. [...] Kali Francišak Skaryna skončyŭ nawuki u Wilni, Babič swaim koštam pasłaŭ jaho wučycca wyšejšych nawuk u Krakoüskuju Akademiju. [...] Widać tahočasnaja Krakoǔskaja biełaruskaja drukarnia była za mała dla drukawańnia Biblii, dziela taho Skaryna pajechaŭ drukawać jaje ažno u Českuju Prahu ${ }^{14}$.

Tu jeszcze Skoryna przedstawiony został jako kontynuator dzieła Fiola bez wspominania imienia ostatniego.

W tym samym numerze „Naszaj Niwy” ukazał się inny artykuł, w którym autor próbował dowieść wyższości kultury białoruskiej nad polską: bo bietaruski pierekład biblii drukawaŭsia na 40 hadoŭ (1517 h.) raniej czym polski, bo ŭ samym sercy Polszy - Krakowi nia polskaja drukarnia byta pierszaj ale bietaruskaja ${ }^{15}$.

${ }^{13}$ Беларускія пісьменнікі: біябібліяграфічны слоўнік. У 6 m., t. 5: ПестракСяўрук, пад рэд. А. В. Мальдзіса, рэдкал.: І. Э. Багдановіч і інш., Mińsk 1995, s. 335-356.

${ }^{14}$ Kali drukawatasia..., s. 563.

${ }^{15}$ W. Citowicz, Z naszaho žyćcia, „Nasza Niwa” 1909, nr 39, s. 558. 
W Karotkaj historyi Biełarusi z 1910 roku czytamy:

Pieršaja biełaruskaja Biblija pierettumačena była z łacinskaj mowy na biełaruskuju Franciškam Skarynaj z Połacka. Widać tahočasnaja krakoŭskaja biełaruskaja drukarnia była za mała dla drukawańnia Biblii, dziela taho Skaryna pajechaŭ drukawać jaje ažno ŭ Českuju Prahu, hdzie pačaŭ druk $\breve{u} 1517$ hadu, a pracawaŭ tam da 1520 hoda. Tym časam u Wilni staraniem Babiča, burmistra hor. Wilni, załožena była wialikaja drukarnia. Tady Skaryna wiarnuŭsia ŭ Wilniu i tut ǔžo dakončyŭ druk biblii u 1525 hadu ${ }^{16}$.

Z tego fragmentu pracy Łastowskiego można wywnioskować, że autor był przeświadczony o istnieniu w czasach Skoryny drukarni białoruskiej w Krakowie, chyba tej samej, w której pracował Fiol.

Kolejny artykuł o Skorynie, którego autor pozostaje nieznany, pojawił się w 1913 roku w książce Колядная пісанка. Cechą charakterystyczną tej pracy jest zamieszczony na okładce ornament zapożyczony ze strony tytułowej Biblii, wydanej przez Skorynę w Pradze w latach 1517-1519. Z publikacji tej można wywnioskować, że

год выданьня Бібліі Скорыны, гэта эпоха у культурным жыциці берарусой [!], і дзеля гэтаго у 1917 гаду беларускіе літэратурные i навуковые кругі манящиа сьвяткаваць 400 лецьце беларускай літэратурьв ${ }^{17}$.

Artykuł świadczy zatem, iż Skoryna w oczach działaczy białoruskich stał się założycielem całego piśmiennictwa białoruskiego. Tekst o podobnej treści ukazał się w 1916 roku $^{18}$.

W 1914 - jak wspominał w 1917 roku pisarz Maksim Horecki „рыхтавалася беларускае грамадзянства святкаваць 400-лецце беларускага друку”. Był to pomysł Łastowskiego:

${ }^{16}$ Włast, Karotkaja historyja..., s. 126-127.

${ }^{17}$ Доктар Франџімак Скарына (Перэкладчык Бібліі на беларускую мову) [w:] Колядная пісанка, 1913 год, Вільня 1913, s. 4.

${ }^{18}$ 400-lećcie biełaruskaj literatury. 1517-1917 [w:] Biełaruski kalendar na 1917 hod, Wilnia 1916, s. 17. 
Дзеяч беларускі, ауттар „Гісторыі Беларусі” Власт, шчэ тады пачай закладащь беларускае таварыства імені Скарыны, [...] і ўжо запрасіў шмат таварышаа ${ }^{19}$.

Maksym Bohdanowicz w liście do Łastowskiego jeszcze w październiku 1913 roku zapewniał:

Калі таварыства імені Скарыны закладзещиа, я ахвотне запішуся у члены. Узяўся б і напісаџь жыциёапісанне Скарыны, калі б таварыства даручыла мне гэта ${ }^{20}$.

W listopadzie 1913 roku Bohdanowicz informował Łastowskiego, że dopiero pisze tekst o Skorynie (калі пакончу са Скарыной), natomiast w maju 1914 roku został już naszkicowany życiorys drukarza: „Я напісаў апрыч яго ўласнай біяграфіi асобны раздзел, дзе падаў характарыстыку папярэдняга беларускага культурнага жыцця і пісьменнасці". Tekst ten nie zachował się, rękopis do 1941 roku był przechowywany w archiwum Akademii Nauk BSRR ${ }^{21}$.

Wydawać się może, że właśnie pod wpływem Łastowskiego działalność Skoryny znalazła odbicie w poetyckiej twórczości Maksyma Bohdanowicza. Łastowski świadomie wspierał twórczość Bohdanowicza, zachęcając go do współpracy z „Naszaj Niwaj” i inspirując tematami z przeszłości ojczyzny ${ }^{22}$. Od połowy 1909 do połowy 1912 roku $^{23}$ napisał Bohdanowicz wiersz Безнадзейнасьць, wydany w 1913(1914) roku w zbiorze poezji Вянок, w którym, bodaj jako pierwszy w literaturze białoruskiej, ukazał postać Skoryny:

Скарына, доктар лекарскіх навук, У доуггай опратиы на вежы сочыць зоры.

${ }^{19}$ М. Гарэцкі, Tворы, Mińsk 1990, s. 205.

${ }^{20}$ М. Багдановіч, Поўнық..., s. 255.

${ }^{21}$ Ibidem, s. 256-258, 338.

${ }^{22}$ В. Корбут, Ад Мінска да Вільні. Гісторыя Беларусі у журналісикіх нататкax, Mińsk 2016, s. 417-423.

${ }^{23}$ М. Багдановіч, Поўны збор твораў. У 3 m., t. 1: Вершы, паэмы пераклады, наследаванні, чарнавыя накіды, Mińsk 1992, s. 586. 
Яны спрылющь! Час! 3 рухавых рук

Скарыны пье адвар пан земскі пісар хворы ${ }^{24}$.

O Skorynie jako wydawcy Biblii w Pradze oraz ksiąg w Wilnie wspominał Bohdanowicz w artykule Белорусское возрождение, napisanym w 1914 roku, a opublikowanym w latach 1915 i 1916. Bohdanowicz pisał о Skorynie jako jednym z pierwszych działaczy białoruskich: „Один из лучших представителей нарождавшейся тогда [w XVI wieku $-V$. K.] белорусской интеллигенции" 25 .

W 1916 roku Łastowski podkreślał szczególne znaczenie działalności wydawniczej Skoryny:

U 1517 hadu Doktar Fr. Skaryna ,dziela lepszaho wyrozumieńnia ludu pospolitamu” drukuje u Prazi czeskaj Bibliju, pierekładzienuju na mowu naszaho narodu. U 1525 h. Skaryna pieranosić swaju drukarniu u Wilniu, $i$ ad hetaho czasu paczalisia chutka mnożycca Biełaruskije drukarni i druki ${ }^{26}$.

W lutym 1917 roku na łamach „Homana” Łastowski opublikował odbitkę ryciny z Biblii, wydanej przez Skorynę w Pradze i z jego podobizną opatrzoną podpisem: „Да 400-лецьця беларускго [!] друку. Францішк Скарына, пераклаў Біблію на беларускую мову і надрукаваў яе ў 1517 гаду"27. Przy rycinie został umieszczony artykuł Łastowskiego, w którym autor wyjaśniał, dlaczego Skorynę oraz jego współczesnych należy uznawać za Białorusinów:

У XIV сталещььці з асобных племён беларускіх утварыуся ужо адзін суцээьны Беларускі народ. Гэто мело вялікі ўлльу на нацььоналізацію асьветьл: з гэтаго часу шпаркімі крокамі пачынае нама

${ }^{24}$ М. Богдановіч, Вянок. Кніжка выбраных вершоў, Вільня 1913, s. 46.

${ }^{25}$ М. Багдановіч, Поўны збор твораў. У 3 m., t. 2: Мастацкая проза, пераклады, літаратурныл артыкулье, рэцэнзіі $і$ нататкі, чарнавыя накіды, Mińsk 1993, s. 261.

${ }^{26}$ W. Ł., 1491-1916, s. 2.

27 „Гоман” 1917, nr 14 (106), s. 2. 
пісьменнасиьь ачышчащйа ад иุаркоўна-славянскіх ўпльвваў і штораз бліжэй падходзіизь да народнай мовьь ${ }^{28}$.

W styczniu 1917 roku Łastowski przypominał czytelnikom „Homana", że „sioletni 1917 hod - heta hod wialikaho nacyonalnaho biełaruskaho jubileju: 400 letniaja hadaŭščyna nadrukawańnia biełaruskaj Biblii” ${ }^{29}$. Przekonywał przy tym, iż sprawa Skoryny była „narodową”: „Francišk Skaryna rabiŭ hetu wialikuju nacyonalnuju rabotu nie samatuham”, ale przy poparciu uzyskanym od współczesnych: „A u pieršy čarod pamahało Skarynie, kładučy košt, «Wilenskaje Panskaje Bractwo», u katorym była zhurtawanaja ŭsia wydatniejšaja Biełaruskaja znać"30. Mówiąc o kulturalnym znaczeniu dzieła Skoryny, Łastowski twierdził nawet, iż ,ŭ pieršaj drukawanaj pa niemiecku Biblii zamieščany z biełaruskaj Biblii rysunki z herbowymi znakami Franciška Skaryny"31.

Jednocześnie w Mińsku, który w czasie pierwszej wojny światowej był oddzielony od Wilna, ukazywała się gazeta „Вольная Беларусь”. W jej pierwszym numerze, jako przykład osiągnięć Białorusinów w porównaniu do „Moskowszczyzny” (biał. Маскоўшчьна), podkreślano wysoki poziom „нацыональнай культуры на Беларусі” na terenach „Літоуска-Рускаго гасударства”, oraz fakt, iż „,y 1517 годзі Францішак Скарына узяу на сябе справу вялікае вагі, - перэклау і выдау Біблію на Беларускай мові"32. Skoryna stawał się zatem bez wątpienia czołową postacią całej białoruskiej historii. Jego wagę podkreślało dodatkowo pochodzenie z Połocka oraz decyzja wydania ,księgi ksiąg” Biblii.

O znaczeniu Biblii w kształtowaniu świadomości oraz języka narodowego w przeszłości i teraźniejszości pisał Roman Szul, podkreślając, ,kryterium posiadania przekładu Biblii jako kryterium nobilitacji

${ }^{28}$ B-a, Кароткі нарыс развіцьияя асьветь на Беларусі да першай чвэрияі XVII сталецьия, „Гоман” 1917, nr 14 (106), s. 3.

${ }^{29}$ W. Ł-ski, U 400-letniuju hadauščynu, „Homan” 1917, nr 7 (99), s. 2.

${ }^{30}$ Ibidem.

${ }^{31}$ Ibidem.

32 „Вольная Беларусь”, „Вольная Беларусь” 1917, nr 1, s. 1. 
języków i odróżniania języków od dialektów"33. Ta właśnie zasada była i jest aktualna dla języka białoruskiego, którego „dojrzałość” potwierdza szesnastowieczna Biblia Ruska (uważana przez białoruskich działaczy za „,białoruską”), wydana przez Skorynę.

Znaczenie Skoryny oraz jego dzieła w świadomości publicystów białoruskich stopniowo rosło. Specjalny artykuł poświęcił Skorynie na łamach gazety „Вольная Беларусь” w 1917 roku pisarz Maksym Horecki (biał. Максім Гарэикі). Uważał on język Skoryny za białoruski z wpływami cerkiewnosłowiańskiego, czeskiego, polskiego i litewskiego: „Але ўсё да меры”. Horecki przypominał czytelnikom o pomyśle Łastowskiego obchodów rocznicy druku białoruskiego, zastanawiając się przy tym nad reperkusjami:

Власта нямецькая хваля захапіла у Вільні, $і$ ияпер немаведама, ичі робіциа тама што-якое дзеля усспаміну намага вялікага доктара [Skoryny - V. K.], иі нарыхтаваліся там як мае быць да гэтага нацььянальнага свята, як было тое на думиы ў Власта? ${ }^{34}$.

Świadczy to o tym, iż przed 1914 rokiem wśród członków koła „Naszaj Niwy" istniała już - dzięki oświatowym zabiegom Łastowskiego świadomość znaczenia Skoryny w dziejach narodu białoruskiego. Ale po 1915 roku, kiedy linia frontu niemiecko-rosyjskiego rozdzieliła obszar Białorusi na dwie części, wizję działalności Skoryny kreowano niezależnie w Wilnie i w Mińsku.

Wychodząc poza ramy czasowe omawianego w niniejszym artykule tematu, warto dodać, że po głębszych badaniach literatury naukowej Łastowski w swych kolejnych dziełach poświęconych Skorynie nieco skorygował własne dotychczasowe ustalenia. W 1924 roku pisał:

Дзеля таго, ито у родным яго [Skoryny - V. K.] Полачку ня было спрыяльных варункаў, а ў Кракаве, дзе ён атрымаў вылшэйшую асьвету, друкаваньне славянскіх кніг, разпачатае Фіолям у 1491 гаду, было спынена дзякуючы иеемначе і фанатызму тамтэйшага духа-

\footnotetext{
${ }^{33}$ R. Szul, Język..., s. 26.

${ }^{34}$ M. Гарэцкі, Tворы, s. 205.
} 
венства, то Скарына, сабраўшы патрэбныя старыя рукапісы, паехаў у Прагу (,старое место Пражское”). Прага маніла да сябе Скарыну таму, ито там, у тыя часы, была поўная рэлігійная свабода, і ён спадзяваўся, што там яго ня сустрэне доля Фіоля ${ }^{35}$.

Czy Skoryna wiedział o istnieniu Fiola? Na ten temat brak wzmianek w źródłach.

Znamienna jest jedna $\mathrm{z}$ przemian w świadomości Łastowskiego, który w 1924 roku już nie zawahał się nazywać Skorynę Rusinem, tłumacząc czytelnikom znaczenie tego określenia:

Скарына называе сябе у сваіх кнігах „русіном”, „рускім”, „нароженый в рускомъ языку" (ў прадмове да кніг Даніэля), сваю дзейнасьиь пасьвячае „своей братии Руси”, сваю Біблію называе: „Бивлія руска выложена докторомъ Франциском Скориною богу ко чти и людем посполитым к доброму научению”. Гэта паказуе, ито Скарына прыналежаў да уусходняга, праваслаўнага абрадку, які у нас называўся ад найдаўнейшых часай „русской верой”зб.

W taki sam sposób interpretował dawne znaczenie słów Ruś, Rusin, ru$s k i$ (raczej jako konfesjonim niż etnonim) polski historyk Henryk Paszkiewicz ${ }^{37}$. Łastowski na temat języka książek wydanych przez Skorynę miał w 1924 roku zdanie następujące:

Кнігі друкаваў Скарына некаторыя на изаркоўна-славянскай мове (Псалтыр, Апостал), а іншыя на тагочаснай нашай літэратурнай мове. Псалтыр і Апостал былі вельмі пашыраны, дык Скарына агранічыууся толькі рэдакційнай папраўкай тэксту $і$ дадаткам тлумачэньняў у крыўскабеларускай мове, а такжа памешчаньнем на белягах кнігі слоў, незразумельх для чытачоў ${ }^{38}$.

${ }^{35}$ В. Ластоўскі, Доктар Франц̧іш Скарына (1525-1925), „Крывіч” 1924, nr 2(8), s. 7.

${ }^{36}$ Ibidem, s. 3.

${ }^{37}$ H. Paszkiewicz, Powstanie narodu ruskiego, Kraków 1998.

${ }^{38}$ В. Ластоўскі, Доктар..., s. 8. 
Jest to zgodne z późniejszymi poglądami językoznawców białoruskich, iż język Skoryny to cerkiewnosłowiański „3 моцным элементам жывой беларускай мовы і са слядамі літаратурнага ўплыву чэшскай і польскай моў"39.

W pracach następców Łastowskiego Fiol jest właściwie nieobecny, Skoryna zaś został uznany za pierwszego drukarza zarówno Białorusinów, jak i wszystkich Słowian wschodnich (Rusinów). W powyższym stwierdzeniu w rachubę wchodziło nie tylko nieruskie (w tym także niebiałoruskie) pochodzenie Fiola. Według Miroslava Hrocha,

do tego, aby pewien bohater czy wydarzenie historyczne mogli stać się przedmiotem emocjonalnej adoracji, trzeba byto, aby członkowie rodzacego się małego narodu mieli o nim pewne wcześniejsze informacje ${ }^{40}$.

$\mathrm{Na}$ początku XX wieku nie było już wątpliwości co do pochodzenia Rusina Skoryny z Połocka. On sam pisał na przykład, że „Книги ЇудиӨъ вдовици починаютьсњ. Зүпольне выложены на рускии њзыкъ докъторомъ Франъциско(м) Скориною, изъ славнаго града Полоцька"41. Przynależność Połocka do obszaru białoruskiego w późniejszych czasach nie podlegała dyskusji, dlatego Skoryna bez trudu został zaliczony do grona bohaterów dziejów Białorusi.

W publikacji z 1924 roku na łamach redagowanego przez Łastowskiego czasopisma „Крывіч”, wydawanego w Kownie, zaproponował on, by obchody 400. rocznicy druku białoruskiego odbyły się w 1925 roku, licząc od czasu, kiedy Skoryna zaczął wydawać książki w drukarni w Wilnie. Wymowne jest przesunięcie obchodów z 1917 roku (jak wcześniej postulowano), to znaczy od rozpoczęcia druku książek przez Skorynę w Pradze. Jednocześnie nie wysuwano już propozycji, by uczcić druk książek przez Fiola w Krakowie, aczkolwiek w 1916

${ }^{39}$ А. Жураўскі, Гісторыя беларускай літаратурнай мовы, т. 1, Mińsk 1967, S. 153 .

${ }^{40}$ M. Hroch, Małe..., s. 150.

${ }^{41}$ Хрэстаматыя па гісторыі беларускай мовы, ч. 1, рэд. Р. І. Аванесаў, скл. У. В. Анічэнка і інш., Mińsk 1961, s. 108. 
roku Łastowski obwołał go tym, od którego działalności ,paczynajecca biełaruskaja drukawanaja literatura"42. Widocznie później Łastowski już nie zaliczał dorobku tego drukarza do ,wydarzeń białoruskich”. Drukarnia „białoruska”, za którą uważano wcześniej drukarnię Fiola, została prawie ,zapomniana"43.

Wydanie przez „Białorusina” Skorynę Biblii w języku „,białoruskim” pozostało jednym z kamieni węgielnych białoruskiej tożsamości i podstawą poczucia wyższości kultury białoruskiej nad polską i rosyjską. Miało to ogromne znaczenie w rywalizacji o białoruskie ziemie pomiędzy Polską a Rosją. Do dziś osoba Skoryny jest ważnym argumentem w sporach ideowych Białorusinów pozostających wciąż pod wpływem kultury rosyjskiej. Na dzisiejszej Białorusi działalność Skoryny jest dobrze znana. Co więcej, według sondażu socjologicznego z lat 2008-2009 pozostaje on absolutnym liderem w kategorii ,przykład postaci historycznej" ${ }^{44}$.

W artykule z 1914 roku, poświęconym 350-leciu początków druku w Moskwie, Łastowski poruszył z kolei kwestię pochodzenia jednego z pierwszych drukarzy moskiewskich Piotra Mstisławca. Zdaniem publicysty, który miał na myśli miasto Mścisław, nazwisko drukarza wskazuje, że „ён родам Беларус могілеўск. губ”. Rozwijając myśl, Łastowski zauważył, że „Мсціславец, апынуўшыся у Маскве мог вызвацца абарудаваць друкарню, бо у сябе дома, на Беларусі, азнаёміўся з гэтым дзелам"45. Jednak brakuje jakichkolwiek danych o poczynaniach Mstisławca jako drukarza na ziemiach ruskich Wielkiego Księstwa Litewskiego. Wiadomo natomiast, że pierwsi drukarze moskiewscy, Iwan Fiodorow i Piotr Mstisławiec, kontynuowali swoją działalność wydawniczą na terenach WKL. Łastowski podkreślał, że

${ }^{42}$ W. Ł., 1491-1916..., s. 2.

${ }^{43}$ Рэдакція, Юбілейны год, „Крывіч” 2(8)/1924, s. 1.

${ }^{44}$ A. Kazakievič, Współczesna białoruska tożsamość historyczna [w:] Tożsamości zbiorowe Białorusinów, red. R. Radzik, Lublin 2012, s. 261.

${ }^{45}$ Власт, 350 летняя гадаушчына друку у Маскоушчыне, „Наша Ніва” 1914, nr 11-12, s. 1 . 
прытулак першые маскоўскіе друкары знайшлі у Заблудове, (Гродз. губ.) у гэтмана Ходкевіча і тут залажылі [!] Учительное Евангеліе 1569 на пекнай беларускай мове. Пасьля Мсиіславеи пераехаў са сваёй друкарняй у Вільню ${ }^{46}$.

Nie ma podstaw, by mówić o języku Евангелия учительного jako białoruskim, ponieważ był to cerkiewnosłowiański. A teza o białoruskim pochodzeniu Piotra Mstisławca ${ }^{47}$ nadal pokutuje w literaturze naukowej na Białorusi. Znamienne jest, że dwa pomniki Mstisławca (jeden został odsłonięty w czasach sowieckich, drugi zaś w niepodległej Białorusi) zdobią miasto Mścisław.

W Karotkaj historyi Biełarusi Łastowski uwydatnił rolę Mamoniczów w dziejach Białorusi, uważając ich za kontynuatorów dzieła Skoryny:

Babič pieredaŭ swaju drukarniu kala 1575 hodu braćciam Mamoničam, rodam z Mahilewa. [...] U hetaj drukarni biez piererywu drukawalisia biełaruskije knižki až da XVII stalećcia. U joj nadrukawany byŭ $i$,Statut Litoŭski" pa biełarusku pad redakcijej znamienitaho kanclera Wialikaho kn. Litoŭskaho Lwa Sapiehi, i mnoha roznych inšych knih ${ }^{48}$.

W 1916 roku Łastowski wymienił drukarnię Mamoniczów w Wilnie zaraz po skorynowskiej, pomijając przy tym działalność wydawniczą na ziemiach ruskich (w tym białoruskich) innych drukarzy cyrylickich, jak Iwan Fiodorow, Piotr Mstisławiec, Szymon Budny czy Wasyl Ciapiński $^{49}$.

W Karotkaj historyi Biełarusi z 1910 roku Łastowski przypominał, że „kniaź Mikałaj Radziwiłł Čorny załažyŭ u 1562 hadu biełaruskuju drukarniu ŭ Nieświežy"50. Omawiając w artykule z 1917 roku dzieje

\footnotetext{
${ }^{46}$ Ibidem.
}

${ }^{47}$ Г. Галенчанка, Мсиіславеи Пётр Цімафеевіч [w:] Эниыыклапедыя гісторыі Беларусі, у 6 m., т. 5: M- Пуд, рэд. Г. П. Пашкоў, Mińsk 1999, s. 224.

${ }^{48}$ Włast, Karotkaja historyja..., s. 127.

${ }^{49}$ W. Ł., 1491-1916..., s. 2.

${ }^{50}$ Włast, Karotkaja historyja..., s. 127. 
reformacji w XVI wieku na Białorusi, wymieniał drukarnię założoną w Nieświeżu przez Mikołaja Radziwiłła Czarnego: „Z hetaj drukarni wyjšli pa biełarusku kalwinski katechizm i Biblija, pracaj Symona Budnaho i Macieja Kawečynskaho". Budnego zaś uważał Łastowski za współdziałacza Radziwiłła, a dzięki ich staraniom w Wielkim Księstwie Litewskim, jak pisał, ,byli atkryty i pabudawany 163 kalwinskije zbory" "51. W 1924 roku Łastowski dodawał, że Kamuxucicb, wydany w Nieświeżu w 1562 roku, był wydrukowany ,літэрамі скарынаўскай стылізаціi”"52.

Budny był przede wszystkim polskojęzycznym działaczem reformacyjnym. Polszczyznę uważał za „nasz język” i bronił jej wtedy, gdy, jak pisał, „łacina lub włoszczyzna z niemczyzną moc u nas biorą" Niemniej w literaturze naukowej na Białorusi przedstawiany jest on jako „бел. мысліцель гуманіст эпохі Адраджэння, [...] прадаўжальнік культ.-асветніцкай, нац.-паліт. і філас. традыцыі Ф. Скарыны" ${ }^{54}$. Taki pogląd można uważać za kontynuację tradycji wpisywania działaczy czasów przed- (Fiol) i poskorynowskich w białoruską narodową historyczną narrację zapoczątkowaną przez Łastowskiego.

Po raz pierwszy imię drukarza z XVI wieku, wydawcy Nowego Testamentu w języku ruskim, Wasyla Ciapińskiego pojawiło się w 1916 roku na łamach gazety „Homan”. W specjalnie poświęconym mu artykule Łastowski pisał: „Ciapinski samatuham zadumaŭ zrabić wialikuju sprawu: wydać Piśmo Światoje dobraj biełaruskaj mowaj” i przypisywał Ciapińskiemu białoruskie dążenia narodowe w czasie, gdy jeszcze nie istniał naród białoruski:

Piersz napiersz, kab uniknuc razbićcia narodu biełaruskaho na roznyje nacii, Ciapinski prasiŭ tahoczasnych panoŭ ,trymacisia jazyka swajho

${ }^{51}$ Reformacki ruch na Biełarusi, „Homan” 1917, nr 18 (110), s. 2.

${ }^{52}$ В. Ластоўскі, Доктар..., s. 11.

${ }^{53}$ Z. Klemensiewicz, Historia języka polskiego, Cz. II: Doba średniopolska (od początków XVI wieku do ósmego dziesięciolecia XVIII wieku), Warszawa 1965, s. 211.

${ }^{54}$ С. Падокшын, Будны Сымон [w:] Вялікае княства Літоўскае: энцылклапедыя. У 2 m., t. 1: Абаленскі-Кадэнцыья, рэдкал.: Г. П. Пашкоў і інш., Mińsk 2005, s. 352. 
pryrožonaho", dy kab jany - wuczylisia hramaty biełaruskaj, zakładali szkoły biełaruskije dla narodu, - ,dziela mitaści da Ajczyzny naszaje,"55.

W 1924 roku Łastowski pisał, że druk Ciapińskiego ukazał się літарамі скарынаўскай стылізаиіiі ${ }^{56}$. W tym przypadku publicysta używał tej samej metody, co w przypadku Budnego: przypisywał Ciapińskiemu cechy działalności Skoryny, który w latach dwudziestych XX wieku był całkowicie zawłaszczony przez białoruską ideę narodową. W owym czasie wśród białoruskiego społeczeństwa obchodzono 400-letnią rocznicę wydania przez Skorynę ksiąg w Wilnie. Z tej okazji ukazało się wiele prac naukowych i publicystycznych (szczególnie w 1925 roku) na Białorusi (w Mińsku, Wilnie) oraz poza jej granicami (na emigracji, w prasie ZSRR) ${ }^{57}$.

Nie można oskarżać autorów pism białoruskich początku XX wieku wyłącznie o świadome manipulowanie faktami. Właściwą raczej odpowiedzią na pytanie o motywacje białoruskich publicystów w przywłaszczeniu tej lub innej postaci historycznej mogą być słowa Miroslava Hrocha, który utrzymywał, że

trzeba wziąc pod uwage, że każdy z historyków byt zwiąany ze swym czasem. Szczerze dażac do doktadnego uchwycenia prawdy o dziejach narodu, w swych rozważaniach i konkluzjach byt pod wptywem pewnych wyobrażen. Miat wtasne pojęcie nie tylko o istocie narodu, ale także o istocie rozwoju historycznego w ogóle. Byt również pod wpływem tego, со јетu wspótcześni uważali za ,interes narodowy”: nie mógt sobie wyobrazić pisania dziejów narodowych w sprzeczności z tym wyobrażeniem $^{58}$.

${ }^{55}$ W. Ł., Wasil Ciapinski, „Homan” 1916, nr 14, s. 2.

${ }^{56}$ В. Ластоўскі, Доктар..., s. 13.

${ }^{57}$ Беларускія пісьменнікі: біябібліяграфічны слоўнік. У 6 m., t. 5: ПестракСяўрук, пад рэд. А. В. Мальдзіса, рэдкал.: І. Э. Багдановіч і інш., Mińsk 1995, s. $335-356$.

${ }^{58}$ M. Hroch, Mate..., s. 130. 


\section{Dodatek 1}

Zmiana imienia Franciszka Skoryny w wileńskim druku białoruskojęzycznym w latach 1909-1917

1517-1519 D. Франъцииска Скорины, N. Франъцииско(м) Скориною (oryginalna pisownia samego Skoryny)

1909 M. Francišak Skaryna, N. Franciškam Skarynaj ${ }^{60}$

1910 N. Franciškam Skarynaj ${ }^{61}$

1913 М. Францішак Скарына, Франціик Скарына, D. Скарыны, Скорьнны ${ }^{62}$

1916 M. Fr. Skaryna ${ }^{63}$

1917 М. Францішк Скарына ${ }^{64}$, Francišk Skaryna, D. Franciška Skaryny ${ }^{65}$

\section{Dodatek 2}

Chronologia pierwszych wzmianek imion wydawców ruskich druków XVI w. z Wielkiego Księstwa Litewskiego i Korony Polskiej na łamach wileńskich druków białoruskojęzycznych w latach 1909-1917

1909 Szwajpolt Fiol, Franciszek Skoryna

1910 Mamoniczowie

1914 Piotr Mstisławiec

1916 Wasyl Ciapiński

1917 Szymon Budny

\footnotetext{
${ }^{59}$ Хрэстаматыля..., s. 105, 108.

${ }^{60}$ Kali drukawałasia ..., s. 563.

${ }^{61}$ Włast, Karotkaja historyja ..., s. 126-127.

${ }^{62}$ Доктар..., s. 4.

${ }^{63}$ W. Ł., 1491-1916, s. 2.

${ }^{64}$ „Гоман”..., s. 2.

${ }^{65} \mathrm{~W}$. Ł-ski, U 400-letniuju ..., s. 2.
} 


\section{Dodatek 3}

Rok, miejsce, postać, od której zaczyna się druk białoruski według wileńskich czasopism białoruskojęzycznych z lat 1909-1917 oraz dzieł Wacława Łastowskiego (WŁ)

1909: 1483, Kraków

1910: 1483, Kraków, Fiol (WŁ)

1913: 1517 , Praga, Skoryna

1914: 1491, Kraków, Fiol (WŁ)

1916: 1491, Kraków, Fiol (WŁ)

1917: 1517, Praga, Skoryna (WŁ)

1924: 1525, Wilno, Skoryna (WŁ)

\section{Bibliografia}

400-lećcie biełaruskaj literatury. 1517-1917 [w:] Biełaruski kalendar na 1917 hod, Wilnia 1916, s. 17.

Citowicz W., Z naszaho žyćcia, „Nasza Niwa” 1909, nr 39.

Hroch M., Małe narody Europy. Perspektywa historyczna, Wrocław-WarszawaKraków 2003.

Kali drukawałasia pieršaja biełaruskaja Biblija?, „Nasza Niwa” 1909, nr 39.

Kazakievič A., Współczesna białoruska tożsamość historyczna [w:] Tożsamości zbiorowe Białorusinów, red. R. Radzik, Lublin 2012.

Klemensiewicz Z., Historia języka polskiego, Cz. II: Doba średniopolska (od początków XVI wieku do ósmego dziesięciolecia XVIII wieku), Warszawa 1965.

Reformacki ruch na Biełarusi, „Homan” 1917, nr 18 (110).

Paszkiewicz H., Powstanie narodu ruskiego, Kraków 1998.

Szul R., Język. Naród. Państwo. Język jako zjawisko polityczne, Warszawa 2009.

W. Ł., 1491-1916, „Homan” 1916, nr 1.

W. Ł., Wasil Ciapinski, „Homan” 1916, nr 14.

W. Ł-ski, U 400-letniuju hadauščynu, „Homan” 1917, nr 7 (99).

Włast, Karotkaja historyja Biełarusi, „Naša Niwa” 1910, nr 8.

Włast, Karotkaja historyja Biełarusi. Z 40 rysunkami, Wilnia 1910.

Ziemkiewič R., Taras Šewčenko i biełarusy, „Naša Niwa” 1911, nr 8. 
Багдановіч М., Поўны збор твораў. У 3 m., t. 1: Вершы, паэмы пераклады, наследаванні, чарнавыя накіды, Mińsk 1992.

Багдановіч М., Поўны збор твораў. У 3 m., t. 2: Мастаикая проза, пераклады, літаратурныя артыкулы, рэиэнзіi і нататкі, чарнавыя накіды, Mińsk 1993.

Багдановіч М., Поўны збор творай. У 3 m., t. 3: Публіиыстыка, лісты, летаnіс жыция і творчасиі, Mińsk 1995.

Беларускія пісьменнікі: біябібліяграфічны слоўнік. У 6 m., t. 5: ПестракСяўрук, пад рэд. А. В. Мальдзіса, рэдкал.: І. Э. Багдановіч і інш., Mińsk 1995.

Богдановіч М., Вянок. Кніжка выбраных вершой, Вільня 1913.

B-a, Кароткі нарыс развічьия асьветы на Беларусі да першай чвэриі XVII сталещьия, „Гоман” 1917, nr 14 (106).

Власт, 350 летняя гадаушчына друку у Маскоушчыне, „Наша Ніва” 1914, nr 11-12.

„Вольная Беларусь”, „Вольная Беларусь” 1917, nr 1.

Галенчанка Г., Мсиіславеи Пётр Цімафеевіч [w:] Эниыклапедыя гісторыі Беларусі, y 6 m., т. 5: $M$ - Пуд, рэд. Г. П. Пашкоў, Mińsk 1999.

Гарэцкі М., Tворы, Mińsk 1990.

„Гоман” 1917, nr 14 (106).

Доктар Франиішак Скарына (Перэкладчык Бібліі на беларускую мову) [w:] Колядная пісанка, 1913 год, Вільня 1913.

Жураўскі А., Гісторыя беларускай літаратурнай мовы, т. 1, Mińsk 1967.

Корбут В., Ад Мінска да Вільні. Гісторыя Беларусі у журналісикіх нататкax, Mińsk 2016.

Ластоўскі В., Доктар Франиііи Скарына (1525-1925), „Крывіч” 2(8)/1924, красавік-сьнежань.

Падокшын С., Будны Сымон [w:] Вялікае княства Літоўскае: эниыклапедыя. У 2 m., t. 1: Абаленскі-Кадэнцьия, рэдкал.: Г. П. Пашкоў і інш., Mińsk 2005.

Рэдакція, Юбілейны год, „Крывіч” 2(8)/1924.

Хрэстаматыя па гісторыі беларускай мовы, ч. 1, рэд. Р. І. Аванесаў, скл. У. В. Анічэнка і інш., Mińsk 1961. 


\section{The figures of Francysk Skaryna and other printers from the Grand Duchy of Lithuania and the Kingdom of Poland in Vilna (Vilnius) Belarusian-language press in 1909-1918 Contributing to the history of shaping Belarusian national stereotypes}

At the beginning of the 20th century, publications devoted to the publishers of the first books in the Church Slavonic and Old West-Russian languages in the Grand Duchy of Lithuania and the Kingdom of Poland began to appear in the Vilna (Vilnius) Belarusianlanguage press. In the articles authored by a well-known publicist Vaclaŭ Lastoŭski, at first it was affirmed that the founder of Belarusian printing was the Cracow printing house Szwajpolt Fiol. Then the role of the first publisher of Belarusian books was attributed to the native of Polack, Francysk Skaryna. Since that time, Skaryna in the minds of Belarusians has been entrenched as a Belarusian printer, although in his epoch (XVI century) the Belarusian nation did not yet exist and Skaryna considered himself Old West-Russian, that is, a representative of a broader community that included the ancestors of Belarusians and Ukrainians, and also inhabitants of the Grand Duchy of Moscow. Thus, Belarusian publicists successfully used Skaryna's personality to create an idea of the existence of Belarusian culture and language in the 16th century and their high level of development. This was an important stage in the process of forming the Belarusian national idea in the early 20th century.

Key wo rd s: Szwajpolt Fiol, Francysk Skaryna, Vaclaŭ Lastoŭski, Vilnius, Belarus 